\title{
Hegel and the Spiritual Evolution of Absolute Subject
}

\author{
Ivo Minkov \\ (South-West University Neofit Rilski, Blagoevgrad; iminkov@swu.bg) \\ ORCID: 0000-0002-5326-7433
}

\begin{abstract}
The article interprets the methodological potential of Hegel's speculative dialectics as a possible course of spiritual evolution of the Absolute subject. The intention is towards the method, first through the very construction of the "idea of freedom" from the point of view of Logic; second, through the constitutive function of freedom and the transition of the subjective spirit into the objective spirit; third, through the unfolding of mediation in the realms of the objective spirit. This essentially substantial methodologization dissolves the theoretical space of the idea of the mediating function of freedom as an ontological principle of ethical life. In line with the paradigm of such a course, the text considers a project of speculative ethics, a project within the framework of which the methodological and ontological sublation of spiritual evolution takes place.
\end{abstract}

Keywords: History of philosophy; ethics; methodologization; mediation; spiritual evolution; Absolute Subject.

\section{Introduction}

In Hegel's philosophy freedom [Freiheit] is an absolute definition of spirit. In the process of attaining freedom, the Absolute Subject ascends to the Supreme Being, enters into a relation with the Other by removing its own and his determination (sublation, in German Aufheben, of the mediation), and as a result merges not with the Other, but with the sublated Other, with Himself. Thus the Absolute Subject arises speculativelydialectically, freely, substantiates in itself both the subjective definite thought and the objective definite thought. Against extreme subjectivism, to which absolute subjectivism can often be attached, it must be said that it is he who does not realize the necessity of his dialecticism, because through it he makes a breakthrough in his own extreme, breaks it and reveals objectivity to him. This spirit, however, is typical of the Absolute subject and lies in the free immanent self-production, in which the immediate opposition between subject and object is removed in the return of the common to itself as a whole (as specifically within itself), where in the generated universal the peculiarity is also understood in an objectivity, where all definitions are sublated. 
This is the spiritual work of the Absolute subject. The becoming of his consciousness and the exhausting work in the field of pure speculative philosophy, in logic, intertwine with each other, as a common spiritual movement in which there is no primacy of one over the other, but the necessity of both positions their unity and differences prevails. Hegel shows the path of freedom, first through Phenomenology of Spirit and the rise of consciousness, as a condition for entering science and logic. The study focuses on the justification of the ethical course of spiritual evolution through the prism of the logical, on the clear explication of the equal importance of "logic" and "ethical life" [Sittlichkeit] in the formation of the Absolute Subject, while suggesting the mutual mediation of logic and ethical life. In this way the research explains the reverse path, which after the education in speculative logic and metaphysics, a more general and complete notion of ethical life is achieved, in general the ethical acquires another form and another meaning, it is transformed and regenerated, ascending spiritually man in his evolutional process. But these opposite paths, by virtue of Hegel's absolute method of knowledge, are in fact identical in content, identical in the doubly mediating and fundamental force, which by an identical method for the two paths (of becoming logic and ethical life) is sublated ontologically in spirit.

\section{Constructing the "Idea of Freedom" from Logic (Freedom as a Speculative-Logical Result)}

Construction is understood as a purely philosophical, that is, speculative exposition of the crystallization of the concept of freedom from Logic. This constitutes the immanent course of the very concept of freedom, its necessary development. And when freedom is often accepted only as the subject of practical philosophy, as the essence of the will, it must become clear that this does not mean looking only for the origin of freedom in this practical, in the external ${ }^{1}$. On the contrary, the ascent to the universality of thought, to the true knowledge of the definitions of thought beyond perception in intuition and representation, is now manifested as necessary also in regard to ethics and ethical life. The concept of freedom and its self-determination and self-realization embodies the totality, the very "idea of freedom". It rises and draws from pure speculative philosophy; moreover, it is also its principle, its absolute basis. The use of this method of cognition as an immanent self-realization of freedom rises from the complete abstractness of logical definitions to the more concrete side of ethical categories. As with formal logic, which is studied first in school, and then education is directed to other sciences, the basis of which is the previous one, so a similar need is manifested in the study of speculative logic. The

1 In his study, V. Duplancic examines the typicality and position of the "idea of freedom" in Hegel's Phenomenology of Spirit, clearly emphasizing from the very beginning that it is not a "patrimony" of practical reason, but rather plays a decisive role in configuring a System of Science. Freedom is not just one of the characteristics of the Absolute, but its very nature "par exellence" (Duplancic 2006, 21). 
latter, however, is not studied in the middle course, but on the contrary, we turn to it only after certain knowledge in other areas of knowledge, i.e., on the way back to formal logic, to a return from the special sciences to logic. In the universality of speculative logic then the riches of the peculiarity are discovered and neither the extremeness of the subjective thinking nor the objective concept of things constitute the truth separately, and the connection of the two parties, the mediating connection - freedom ${ }^{2}$.

Thinking is the realm of freedom. In speculative logic there are no instinctive actions, feelings, sensations. There everything is guided by the tireless course of the concept, of the spirit, which means freedom; a free self-conscious action, detached from self-subjective immediacy and devoted to an objectivity that is not external, but rather immanent objectivity. The comprehension of such objectivity as the self-knowing freedom that has returned to itself is the real reality. The purification of the instinctive impulses from the realm of the logical contributes to its elevation, to the animating of the spirit. Thus, as a pure sphere of intellect, logic contributes to the possibility of pushing the idea of a new speculative-ethical project in which to demonstrate the ethical potential of the Absolute subject, its elevation to freedom and truth [Wahrheit], its spiritual evolution.

With the implementation of the content in logic, a theoretical space for placing freedom as a speculative-logical result is revealed. With speculative logic Hegel puts again the beginning of the real consideration of things, of the concept of things. In the whole circle of logical priority there is the concept, which is both a result and an absolute basis. The concept is in-it-self (this is its formal side), but it is also a certain concept, i.e., it is filled with content, or rather, it is the very content of thinking. The intra-plastic philosophical methodology in the speculative logic explicates the strict course of thinking, its necessary development, in which it has the highest freedom, complete independence. The deduction of the categories from themselves is a direction given by Fichte, but which Hegel leads to the end in his logic and which determines the real side of freedom, the consideration of things for themselves. The nature of the concept as self-determination has the special side of giving itself content and thus reality ${ }^{3}$. At this level, the essence of the Absolute Subject,

2 The American researcher and philosopher A. Wood points out the essential difference in the concepts of freedom, in I. Kant and J. G. Fichte on the one hand and, in Hegel, on the other. Hegel presents Kant and Fichte's views on distinction (Otherness), as completely wrong, as "escape strategy", "self-withdrawal". Kant and Fichte make a sharp distinction between the rational "I" and everything "external", "empirical". Hegel thinks of the necessary connection of the two sides, the necessity of distinction and its overcoming by the subject, making the other his own, entering into it and conquering it (Wood 1990, 44-45). Wood also shows the specific technical (operational) term that Hegel uses in defining absolute freedom, of absolute one's own activity: "To be free in this special way means to be bei sich selbst", "with oneself". In ordinary German bei sich has to main meanings when applied to a person: it means to be awake, conscious, and to have control over oneself. Freedom like Beisichslebstsein refers to human abilities for self-confidence and selfawareness, for self-improvement, but it also has a richer meaning. The original meaning of the German bei is related to the expression of spatial proximity, contact or belonging (cf.). This is the "idea of freedom" as the involvement of the Absolute subject, its intertwining in social relations, its awareness in its own imprint in the world-historical process, the awareness of the necessary connection of all and everything, with the sole purpose of spiritual evolution.

3 In this strong unity of the concept is unlocked the harmony, the necessary connection between concept and reality. R. Pippin points out that this is an "extraordinary connection", "not just 
Hegel's concept and conception of the "idea" in general, as a unity of subjective and objective, begin to overflow. The "idea", according to the German philosopher, is abstract, but also concrete, such as

(...) the free concept, the concept determining itself and thereby determining itself as reality. It would be something formally abstract only if the concept that is its principle were taken as the abstract unity and not as it is, namely, as the negative return of it into itself and as subjectivity (Hegel 2010a, 283).

Here this already become subjectivity differs essentially from the ordinary conception of it as coincidence and arbitrariness. Absolute subjectivity is true reality; it has a being as a spirit. Its work (activity) is the free production, the speculative-dialectical course of mental definitions in their necessary development as a system. Its sole purpose is truth, understood as the conformity of objectivity with the concept: "These objects [Gegenstände] are true if they are what they should be, that is to say, if their reality corresponds to their concept" (Hegel 2010a, 284). Hegel sees the "idea" not as something abducted, but rather as the most real, it is not something beyond, distant, but fully present. In this sense freedom as an "idea" is a constitutive principle in logic (as in the whole philosophical system of Hegel), but also a result, and its own result. It is something immediate, but also something, above all, mediated. In such unity the "idea of freedom" is peculiar; it has its own typicality. It differs both from a self-substantiality and from a onesided subjectivity and crystallizes as the "Absolute idea" existing in-it-self and for-it-self.

The unity of the Absolute Subject should be preserved in this direction of taking away oneself in the one-sidedness of the two positions in themselves. The speculativedialectical method embodies analytical and synthetic relations simultaneously. Such is the philosophical attitude, which must preserve the activity of the concept itself and beware of arbitrary ideas and special opinions, which, as Hegel says, "always want to manifest". The philosophical method is not an external form that sets the content in motion, but appears as the soul of that content; the concept itself. Therefore the research is centered on the analysis of the method, of the own immanent self-development of the concept, which reaches the form of the forms, to the "Absolute form", in which all its definitions return and thus represents a systematic totality. Throughout of the course of The Science of Logic, in the development of logical categories, where the deepest mental strain is required, the nature of freedom is evident. Usually arbitrariness and opinion are perceived as attributes of freedom ${ }^{4}$, but it is with them that the subject is not with himself. Hegel sees arbitrariness as a choice which operates with a reflection that abstracts from everything and is dependent on a particular content or matter (Hegel 2005, XXXVIII). In speculative logic, however, there is no room for arbitrariness and mere subjective whims;

harmony", but "complete penetration" (vollkommene Durchdringung), quoting a paragraph from the Philosophy of Right (Pippin 2000,184).

4 Hegel writes: "Ordinary man believes that he is free, when he is allowed to act capriciously, but precisely in caprice is it inherent that he is not free" (Hegel 2005, XXXIX). 
everything there is permeated by the relentless course of the concept, where the Absolute Subject is with itself, and is a free spirit.

The definition of the Absolute Subject, as a form of attitude towards oneself, includes being a free spirit in oneself ${ }^{5}$. The becoming of the Absolute Subject in itself gradually breaks the shell of the substantial and at the same time raises it to self-consciousness. The Absolute Subject operates with simple negativity, it is its essence, the mediation of becoming another for oneself with oneself. This is the form of subjective spirit in Hegel, the first side of the Philosophy of Spirit and the first requirement in general in the process of snatching from the immediacy of substantial life. The speculative-dialectical course results in a form of the spirit that returns (and at the same time approaches its evolution) to the phenomenological side and focuses on three fundamental relations - to the Supreme Being, to the Other and to Oneself, to pave the way to a possible speculative ethics. As an attitude towards oneself, this form, in turn, is, apart from the unity of the first two relations and thus their result and truth, also the beginning of the indirectly immediate form of a subjective spirit, of a free spirit in itself, which has the inner dialectical urge to do it for oneself, and to focus on the existence of the spirit in oneself and for oneself. This is the ethics of the present form of the spirit, methodologically justified and laid down by mediation in logic. What matters is the spiritual evolution itself. Speculative logic affirms the retreat into the supersensible world of thought and concept. The principle foundation of the methodological perspective, as a meaningful methodologizing, which is necessarily self-directed thinking, becomes the essence, the constitution of the Absolute Subject. It is the methodological basis of the transition from logic to ethical life and vice versa, knowledge that has basis in itself. This is the view of the Absolute Subject towards himself, which holds and comprehends the possibility ${ }^{6}$ and the attempt to build his own ethics of

5 The Absolute Subject is in its become immediacy and must walk the path to the absolute form of subjectivity, which has in principle the logical and ethical spirit and which has in itself the real world. This last form of absolute subjectivity stands against ordinary finite, divisive reasoning, on the one hand, and immediate knowledge, on the other. Extracting the positive from the two popular forms of knowledge and removing the reactionary elements, the Absolute Subject is centered in the speculative, withdraws from the advancing necessity, from the concept that embodies freedom, and with its help directs himself to knowledge of himself and his own evolution. Because the spiritual evolution of the Absolute Subject is the realization of itself, that it reaches the knowledge of itself. Hegel's words are so relevant today:

Besides, it is not difficult to see that ours is a birth-time and a period of transition to a new era. Spirit has broken with the world it has hitherto inhabited and imagined, and is of a mind to submerge it in the past, and in the labour of its own transformation. (...) The onset of the new spirit is the product of a widespread upheaval in various forms of culture, the prize at the end of a complicated, tortuous path and of just as variegated and strenuous an effort. It is the whole which, having traversed its content in time and space, has returned into itself, and is the resultant simple Notion of the whole (Hegel 1977, 6-7).

6 Hegel speaks of the abstract, immediate reality of the spirit, naturalness. But such naturalness must be overcome by the way of spiritualizing, an etherialization (Toynbee's idea for Progress) of man. Therefore, the possible course of the Absolute Subject is an ethical course aimed at one's own spiritual growth and is substantiated by logic, by the concept. Building a path for the Absolute Subject to speculative ethics is possible because it is based on the concept and aims to become reality through the attainment of spiritual evolution. Speculative ethics can be principled 
a speculative order. All this determines the formation of the typological characteristics of spiritual evolution, explicates its essence and way to achievement.

From here, the article focuses on the problem of how this subjective, free-spirited spirit breaks away from naturalness, brings itself into being for itself, and creates its own world in which freedom has being as an available necessity. This real world is known as the objective spirit, the elements of freedom, its derivatives, and the explicit nature of the Absolute Subject in all the richness of its evolving form.

\section{The Constituent Function of Freedom. An Attempt at a Peculiar Topology}

The constituent function of freedom is postulated through the movement forward of development, through the constant becoming and perfection of the Absolute Subject and its forms. According to Hegel, the "idea of freedom", its mediating and constitutive function, is necessarily in the philosophical consideration. In the strictly theoretical and speculative-dialectical course of the research, the objective spirit in which one enters is an adequate expression of the necessary series of certain concepts. The abstract subjective spirit is filled in this movement of development forward, forming the objective and investing it in itself, and, conversely, subjectivity becomes objectivity. He now enters the phenomenological sphere, where the mediated unity of consciousness and self-consciousness points the way to the actual realization of the spirit, to the general transition from subjective to objective, to true reason.

The dialectical movement of the concept (spirit) requires the attitude of the Absolute Subject, as such in-it-self and for-it-self. Contrary to the philosophies of Kant and Fichte, consciousness is directed to its own perfection, not through anything else, but through itself. The attitude to something else is only a step, a necessary stage of spiritual evolution, it is not something incomprehensible, which remains an infinite impetus, but is inserted into the whole process of mediating oneself with oneself. Therefore the spiritual evolution of the Absolute Subject lies in the whole, rational relation, in which subjective confidence rises to truth, resolving its own initial contradiction, escapes from the abstract way of understanding and goes to the concrete nature of things, to the understanding of things in their concepts. Thus, through the essence of the concept of spirit, the subject achieves in himself and for himself evolution, self-improvement. It is a basis and self-movement, selfdevelopment, but at the same times a goal and thus a true result. These dialectical circles explicate the nature of the "speculative" in Hegel, they are all-encompassing and their totality arouses the urge to define, to know, to be uncompromising with regard to the claims about the limits of human knowledge. This Hegelian spirit, the spirit of the concept,

as real, and at the same time the ontological achievement of ethical life in general takes place. Finally, all these paths are conditioned and acquire meaning through the "idea of freedom" and its fundamental, mediating function of a constitutive nature. 
is also a starting point in the transition to objectivity. He dictates the general course of the degrees of subjectivity and objectivity, of their interrelation in the transitions, emphasizing a special analogy. The raising of subjective confidence to truth takes place through the forms of consciousness, self-consciousness and reason. The elevation of objectivity to its truth takes place through the forms of law, morality and ethical life. Here the meaningful methodological transition, from Phenomenology of Spirit to Philosophy of Right (which takes place through Logic), is really significant.

The forms of the subjective spirit are not simply sewn to those of the objective spirit. Significant is the insight for the application of the entire speculative-dialectical activity of the concept, from the subjectivity, in the certain forms of objectivity. The course of consciousness to reason is woven as a methodology in each of the forms of the objective spirit separately, in law, in morality, and in ethical life, thus achieving a kind of systematic topology of freedom, expressing the peculiarity of its derivatives.

In order to grasp a systematic topology of freedom, it is necessary, first, to establish the nature of the will; second, to make law as something internal to the Absolute Subject as morality; and third, to reveal law and morality as a universal ethical spirit. The topological characteristic of law pushes the metaphysical position of legal ideas and presents a broader and deeper view of law - speculative-dialectical. Hegel acknowledged Montesquieu's merit in the systematics of law, albeit mainly in a historical sense. The French thinker understands legislation and its characteristics, not in an abstract way, but rather as a dependent element of the totality, connecting it with the other elements that form the mentality of a nation and an era. It is really important for Hegel that such a comparative-historical approach coincides with the development of legal ideas from the concept. In Philosophy of Right, the German philosopher cites the textbook of Hugo Lehrbuch der Geschichte des römischen Rechts (Textbook of the History of Roman Law) (Hegel 2005, XXVII-XXIX) as an example of the lack of speculative, logical procedure. G. von Hugo (1764-1844), the author of this work acts only within the known ordinary, only reflective and divisive reason and does not reach the constitutive speculative notion of law, in general the truly rational thread in legal matter.

The place of law is in spirituality, in particular in the will, which is free. The constituent function of freedom establishes the substantial, essential characteristics of the will. Hegel explains freedom of the will with reference to nature, emphasizing that freedom is as fundamental to the will as the weight of the bodies: "Will without freedom is an empty word, and freedom becomes actual only as will, as subject" (Hegel 2005, XXIX). A similar analogy is observed between thinking and the will: "The will is a special way of thinking; it is thought translating itself into reality" (Hegel 2005, XXX). And their difference is only as it is in between theoretical and practical in general, i.e., such a difference has its place in the speculative-dialectical course of the concept, but finally it is also removed and unfolded to the higher, to unity. Thus, the nature of the will is best clarified precisely in its connection with thinking and the theoretical. 
In the transition from law [Das Abstracte Recht] to morality [Moralität], Hegel approaches with internal intention and, in this sense content methodological. The notion of morality that is approached is not required externally, but is built internally in the process of becoming law. The German philosopher treats law and its necessary interconnectedness with morality in a completely new, heuristic way ${ }^{7}$. If law is the abstract definition of the will, then morality is its negation, the transfer inward to itself, its own attitude. This is the middle term in the way of defining the will, in its stages of construction and development. But, in fact, both sides are one-sided, and morality also falls into mere abstraction, into abstract negation. Only in ethical life [Sittlichkeit], law and morality do they discover their truth, where the will, as a concept, and will, as individual and subjective, stand in a powerful unity.

In the speculative-dialectical course, the concept of recognition stands out, through which the personal right of the subject and the right of the other subjects are given meaning. This is presented in the movement of "property", in the stages of its development, first, as an immediate act of possession; second, as the use of possession; third, as a waiver of that possession (relinquishment). This development of "property" results in the need for contractual relations between the subjects, where the unity of each particular will is established in a universal will 8 . In the "contract", an entity owns "property" within the meaning of the universal will. The logical course of the concept is manifested as it passes from the singular and the finite and develops by virtue of its very nature, into something universal. A very important aspect of the "contract" is that each of the two parties does not simply take the opposite position to the other. This has to do with the concept and lies beyond the formal contract and the simple stipulation. On the contrary, each of the parties fulfills obligations under both lines of the agreement, while maintaining its own. Dialectics is self-generating, alive, it is an exchange between the two sides of the "contract", between two wills. The dialectical nature of the "contract" manifests itself as an analogy of the relationship between "property" and "possession", between the substantial side and appearance. The universal and individual wills differ, have and retain their originality,

7 Some authors understand Hegel's legal theory from a natural law paradigm, emphasizing the distinctive alternative that presents his view of how most natural law theories are traditionally conceived. According to them, Hegel builds an entirely new way of thinking about the relationship between law and morality (Brooks 2017). Strictly philosophically, however, it must be said that Hegel developed a clear distinction between law and subjective will. The internal approach to the transition from law to morality makes sense because of the ambiguity of the term "natural law" pointed out by the German philosopher, namely whether it is present in a directly natural way or is thought as determined by the nature of the object, i.e., by the concept. The first conception has been developed by a whole galaxy of thinkers, from Grotius to Savigny, and the second, which follows the relentless course of the concept, now requires restriction of freedom, a self-determination of the will and sacrifice of naturalness. Therefore, Hegel cannot be defined as a representative of the natural law paradigm in the ordinary understanding of the expression "natural condition," but only insofar as this expression contains the meaning of the nature of the object, the origin of the concept.

8 Hegel points out: "This reference of will to will is the true and peculiar ground on which freedom is realized" (Hegel 2005, 23). 
but at the same time they stand in unity. The universal will resist in the agreement, and the individual - in the fulfillment of the obligations under the contract.

Another specific aspect of the "contract", which has to do with the nature of the concept and the peculiar topology of freedom, is the essence of its rational treatment, its typology, which is derived not from external circumstances but from distinctions that are included in its true, dialectical nature. These are the differences between a formal and a real "contract", between "property" and "possession", and so on, which in turn lead immanently to a deeper difference - the fully realized difference, not only sublated and overcome, but developed, from this extreme and subjective side, the special will, which differs from the universal and becomes non-legal [Unrecht]. And Hegel points to the very high need for this transition to non-law, from the point of view of logic. Because the course, the dialectic of law requires, or rather represents the non-law, the special and accidental will, which opposes the law itself. On the one hand, this particular will is aimed at denying the concept of recognition, which is essential for law as such. He separates himself from it by observing only its formal part and disregarding its true value, its content. On the other hand, further in the definition of the will (as non-right) it is declared against the formal and substantive side of the recognition, and hence of the law in general, and it becomes a violent-evil will - a "crime" (Hegel 2005, 30). All these definitions of the will require the existence of the judicial system that regulates the relations of the many different special wills and this is a necessary part of the topology of freedom, of its actual development and realization in a state or civic community. The need to punish crimes for the purpose of retribution and justice for the injured party, in order to discipline the special will, is a huge section of law - criminal law. The essence and meaning of criminal law is to deny the negation of the right caused by the violent-evil will. The negation of negation, as a basic principle in speculative logic, is applied in the legal system, giving rise to the actual appearance, the application of justice [Gerechtigkeit] ${ }^{9}$. As Wood rightly points out, all this corresponds directly to Hegel's metaphysics, where one thing presents its truth and reality, when it is able to endure otherness and contradiction, and then to return to itself from its own opposite (Wood 1990,110).

The speculative-dialectical course of the will passes in the transition from law to morality and more concrete in the specifics of the latter. The resulting form of freedom, of the will as a right, is, so to speak, the external side, which aims at the regulation of human

9 In his major work The Theory of Justice (1925) where a critical analysis of the concept of justice was made, the German philosopher of law R. Stammler pointed out that the intention of the right to realize justice was not the result of any external circumstances, is not its secondary nature, but rather is given by the very concept of the law and the purpose of the institution representing it - the court. That is why Stammler argues that every right, every law is essentially an attempt to enforce justice (Stammler 1925, 21-25). Stammler's philosophy of law is critical because he was influenced by Kant and neo-Kantianism (Stammler was friends with P. Natorp, one of the cofounders of the Marburg School). He transformed legal philosophy by shifting its focus from the simple equating of morality to simple abstract rules, to the relation of morality to the problem of justice, in the administration of law in specific cases. Stammler rejects the historical and analytical approach, considering them insufficient, and turns to a critical content methodology attempting to introduce a new "critical jurisprudence" (Sabine 1933, 322-232; 350). 
behavior from the outside. Morality is the internal form through which the concept of will (freedom) continues its development and further definition in order to result in the unity of the two forms, which determines the constitutive nature of freedom. The immanent course of law is based on the dialectical nature present in the legal system ${ }^{10}$. The first and immediate form of abstract law should be sublated and overcome, as is the movement of categories in speculative logic, and the next stage in the realization of the will is expressed in its involvement in the opposition of the abstract universal and independent particular. This opposition is again removed, through the negation of negation, and the will actualizes itself as a real freedom that already has the potential to relate itself to itself. Hegel writes: "The subjectivity which is its own object is infinite, and freedom in its infinite subjectivity constitutes the principle of morality" (Hegel 2005, 40). Or, as in Phenomenology of Spirit, self-consciousness is the truth of consciousness, which has evolved to the point of relating to itself, the object of study is itself. The concept of freedom progresses from abstract law to the degree of a self-determining and self-relating subject.

The special role of the concept of morality in Hegel's system is indisputable. It has its own evolution, which is necessarily linked to the development of Hegel's speculative, systematic thinking. There is a difference between the concept of morality in the early and later periods of its philosophical maturation. In his earliest manuscripts, from Tübingen (1793) and Bern (1794-1796), Hegel addressed problems primarily on religious themes and the history of religion. In Frankfurt (1796-1800) theological pursuits continued, even deepening, going beyond morality through the teachings of Jesus Christ. And if in the two previous periods of Hegel's philosophical growth there was an attitude, especially to Kant and the second Critique, then in Jena (1801-1806) "Along with the construction of the speculative system, Hegel's views on morality continued to develop mainly in response to Fichte's ethical writings written during his own Jena period (1794-1799)" (Wood 1990, 131). In all periods of his development, however, Hegel always has in himself a common, holistic view of morality as a one-sided part of ethical life. This is evident, again, in Phenomenology of Spirit, where a contradiction grows between the "systematic superiority of ethical life" and the "historical superiority of morality" (Wood 1990, 133). Hegel's Jena manuscripts lay the groundwork for asserting and affirming the thesis that morality is a positive, albeit, limited form of ethical life. Morality is the ethical life of the modern bourgeois world, the subjective moral freedom, in the European sense of the word.

In the speculative-dialectical determination of the will, the course of subjectivity to

10 There are two fundamental paradigms in jurisprudence - "natural law" and "positive law". The first binds law and morality; the second, on the contrary, does not unite, but separates law and legislation from morality and ethics. Legal positivism, as a result of the logical positivism in which it finds its philosophical rationale, seems to be the more widespread view of law in general, in the twentieth century. The main idea is to promote the notion of "pure theory of law", beyond morality and politics, as "pure science of law" (jurisprudence) (Kelsen 2005). In the $21^{\text {st }}$ century, however, the trend seems to be changing and more and more talk, and above all, to demand morality in politics, law and the judiciary. 
objectivity is paved. The subjective will have an impulse to turn to objectivity by virtue of the deep principle clearly unfolded in its fullness in Hegel's speculative logic. This is a principle of the identity of internal and external, which is applied to morality, arguing that what is the will "from within" must be judged by its external actions: "The subject is the series of his acts. If these are a series of worthless productions, the subjectivity of the will is also worthless; if the acts are substantial and sound, so likewise is the inner will of the individual" (Hegel 2005, 52). Law immanently gives rise to subjectivity. Morality, free subjective will, in turn requires objectivity, the construction of a whole, the existence of an absolute will. The limitation, the extreme of morality, manifests itself in two aspects, as the abstract, unrealized good, and as the abstract subjectivity. These are the specific elements in which freedom receives its development, differentiates the degrees and intensity of its metaphysical position and constitutive function. The philosophical consideration of freedom establishes the need for such a totality, of a complete process, from the point of view of law, towards the point of view of morality, the result of which is ethical life, the unified spirit, which is at the same time the basis of the first two. Absolute will, which is becoming a subject only now, as a universal ethical spirit, contains all the previous elements, not only as an objective spirit and topological spheres of freedom, but also as a speculative-logical and dialectical course of mediation. The logical basis paves the way for the ethical and makes an attempt to elevate the latter to the level of a specific, concrete science. The interplay of the "logical" and the "ethical" opens up the possibility of spiritual evolution, and the Absolute Subject uses philosophical treatment to achieve this goal. In scientific philosophy, which is beyond arbitrary beliefs and simple sensations and relies solely on the concept, one can trace the development of the concept of freedom, which means the overall formation of absolute subjectivity, its spiritual evolution and its own ethics. Therefore, the whole course of research is directed to this development of the concept of freedom from the "logical" and its phenomenological prerequisites, to the "ethical" and typological characteristics of spiritual evolution in general.

Next, the mutilation of ethical life without freedom should be shown first (in order to further support the strength of its constituent function); second, to reveal mediation as an ontological principle in general; and, third, to demonstrate the mediating function of freedom as an ontological principle of ethical life.

\section{The Mediating Function of Freedom as an Ontological Principle of Ethical Life}

The concept of freedom develops and unfolds both to the external reality and the essence of self-consciousness. Only through the concept of freedom and its meaning are known the phases of ethical life, its system and the relationship of the elements. This derivation of ethical life, from the point of view of freedom, the showing of the insolvency of the former in the absence of the latter, refutes the immediate conception of unnecessary 
evidence in the ethical sphere. On the contrary, the necessity of such evidence and the strictly scientific treatment of ethical issues as an essential aspect of the speculative, of the philosophical in general are affirmed. Freedom is a springboard for ethical substance and evolution of its elements. Thanks to it (as a speculative-logical result) the ethical person, the Absolute Subject has the potential to be spiritually uplifted, immanent and necessary transformed, setting the course of identical change in the laws and constitution of his state, its institutions.

The essence and the meaningful interpretation of the "law" [Gesetz] set the parameters and the potential of the Absolute Subject, an ethical person filled with the power of free thought and substantial life. As a logical category, the "law" is considered in the system of categories of essence, in the transition to necessity, as the latter is revealed as a characteristic of the law. In the field of ethical life the main type of law is preserved and passed methodologically. The theory of duty, which as undeveloped by philosophical, i.e., speculative point of view, as found in Kant and Fichte, based on the principle of moral subjectivity, is unsatisfactory. On the contrary, Hegel presents a new concept of duty, which is developed in terms of its own content and its logical formulation as the development of relations that are necessary in the sense of freedom and are in fact in their entirety real (Hegel 2005, 78). This is found only in the state, where the laws find their full expression and are a real explication of freedom.

In the development of the ethical thought of the late Hegel (from Philosophy of Right), ethical life is speculatively and in principle nurtured by freedom, "reconciling" in Wood's apt expression (Wood 1993, 216-217). Aristotle's traditional ethical theory with Kant's and Fichte's emphasis on personal freedom (in an abstract sense). Hegel of Berlin puts a different meaning into ethical life, unlike Frankfurt and Jena, focusing on the construction of a complete system of ethical life, as relations and mediations of its elements, of its immanent speculative-dialectical self-realization. The self-development of the concept of freedom is the only basis and instrument that gives ethical life, a real life and fullness, because freedom makes itself objective and thus real. Therefore, the personality becomes ethical, the subject becomes absolute, only when the spirit of freedom does not stand only in its reflective and finite-subjective form, but is considered and realized simultaneously from its objective side. As a whole, as a system, in the relations of subjective and objective ethical life acquires its new form, of a single spirit and organic unity, the self-created freedom, so powerful as to claim the most general regularity and ontological principle. Thus, the true understanding of the category of "law" determines the transition to such general laws and further strengthens the justification of mediation as an ontological principle in general.

The speculative-dialectical treatment of the law conducts its systematics beyond the claims of perfection, on the one hand, and insolvency and arbitrariness, on the other. The basis of law should be sought only in thinking, in the spiritual. Only in this way the law is constituted and substantiated, and is valid and known. Free thinking has its 
constitutive function to lead to universality a specific feature, and its mediating function to remove the uniqueness in the community. This united result is the spirit of the laws, the spirit of the state and of a nation. The need for laws arises from the system of wants (needs) and the regulation of relations to achieve human wants through labour. It is also conditioned by the application of the law to the relations in the civic community related to "property," the "contract," to the ethical and economic relations, as well as to the own internal needs, arising from justice and the state ${ }^{11}$. The unity of the individual feature and the legal universality is also manifested in the law ${ }^{12}$. The universality of law represents the state, and the individual feature - the individual citizen. In the law as known by the citizen the mediation between the latter and the state takes place. The state as a self-developing whole and self-conscious ethical substance, also knows the law and the community of law. In the development of its moments and, mainly through the essential principle - the "basic law" - the "constitution", the state receives "(...) the form of a known community". The unifying connection of the law lies as a right of self-consciousness and therefore the laws should be carried out to a degree of universality, to be known. The law embodies the intrinsic nature of abstract law, as well as the essence of self-consciousness. The diversity of peculiarities in civic community rises to the level of universality, removing its peculiarity in the law and recognizing the validity of the rational will of other subjects. Through the law the will becomes objective, realized. That is why the laws, the individual cases in the court in which the law finds its guardianship, should be public; the laws must preserve and maintain the trust of the citizens ${ }^{13}$.

The "state" [Der Staat] is the realm of law. The basic law and the innermost side of a state is its "constitution" [Verfassung $]^{14}$. The speculative-dialectical construction of the state is the relation of development to itself, the preservation of the two necessary pillars - the "family" and "civic community", as well as universal law and individual morality. The constitution of the state preserves the consciousness of its citizens about freedom, expresses and maintains the level that individuals have reached in the understanding

11 Aristotle also said that laws are determined and should be determined by the state system, not the other way around: "The same political insight will enable a man to know which laws are the best, and which are suited to different constitutions; for the laws are, and ought to be, relative to the constitution, and not the constitution to the laws" (Aristotle 1999, 81). Therefore, the laws and legal systems of different peoples, in turn, differ from each other (Hegel 2005, 112).

12 "Right as a rational order opposes arbitrariness and as a general unity of law opposes random details" (Lasson 1967, 271). In his work System der Rechtsphilosophie (Originalausgabe aus dem Jahr 1882), A. Lasson, father of a famous Protestant theologian and co-editor of the collected works of Hegel (Sämtliche Werke, Felix Meiner Verlag 1911) G. Lasson, presents law (Das Recht) as an existing being, an external existence (äussere Dasein) of freedom [Freiheit] (Lasson 1967, 271282).

13 Hegel writes: "Publicity is a right, because the aim of the court is justice, which as a universality belongs to all" (Hegel 2005, 119).

14 Hegel wrote about the constitution in Fragmente einer Kritik der Verfassung Deutschlands, starting the essay around 1799 while still in Frankfurt and finishing it in Jena in 1802-1803. K. Rosenkranz originally attributed the essay to 1806-1808 (Rosenkranz 1844, 235-246), but later admitted that it was completed in 1802-1803. In contemporary research on Hegel's biography, writings, and systematic philosophical growth, the fragment is also dated to the period 1799-1803, but placed in the Jenaer Schriften und Entwürfe (1801-1806) column (Jaeschke 2003, 100-105). 
of the concept of freedom and its realization. In the essence of the constitution as a process of self-construction and immanent establishment, lies the real methodology - the speculative dialectic, the mediating force. The method that permeates the whole philosophical system of Hegel, with which Science of Logic ends, and also Phenomenology of Spirit begins, is the totality, the general regularity and the ontogenesis of the "logical" and the "ethical". In the first, the idea of mediation as an ontological principle in general is justified; and in the second, the idea of mediation as an ontological principle of ethical life.

In the nature of mediation [Vermittlung] lies the meaningful course of selfdirected thinking in its uniformity, the simple becoming ${ }^{15}$ of pure abstraction and its transformation into being. Mediation is the self-conscious freedom, the free, own activity of the spirit, as a thinking subject. The self-igniting power of mediation gives rise to being from an epistemological basis, from a philosophical conceptualization and thematization of cognitive content. At the same time, however, this mediating power of thinking has an essential meaning and does not abandon the ontological content. Mediation as a principle fully embodies both the epistemological and the ontological aspects of Hegel's dialectic. The methodological interpretation of mediation also leads to its ontological aspect, insofar as the method is the soul of all objectivity, and each content has its truth in the form: "For this course the method has resulted as the absolutely self-knowing concept, as the concept that has the absolute, both as subjective and objective, as its subject matter, and consequently as the pure correspondence of the concept and its reality, a concrete existence that is the concept itself" (Hegel 2010b, 737). The result of the mediating activity is a coincidence of the methodological form and the theoretical content, the theory of being corresponds to the theory of knowledge. Hegel combines epistemology, ontology and logic and revives the principle that Kant previously destroyed: the principle of the identity of thought and being. Here he finds its justification and mediation as an ontological principle in general. As a method, mediation was initially understood from its epistemological form and not accidentally, it is the main method in Phenomenology of Spirit. In the latter, the procedural character of the principle of the identity of thought and being, the idea of transition and activity, of the living live in which the truth lies, is carried out. The process conceived in this way is the methodological basis that substantiates the typicality of the spiritual evolution of the individual and of social progress. Mediation is a process in which knowledge is understood and promoted in general, and the constitution of a speculative ontology becomes possible through it.

In mediation lies the meaning of the method, which seeks to realize the concept. The ontological achievement through mediation is realized on the way of taking oneself in

15 W. Lütterfelds (1943-2018) notes in an article concerning Hegel's thesis on the identity of "substance" and "subject" that mediation is an independent equality [Sichselbstgleichheit], "simple becoming" [einfache[s] Werden] is the self-reflexive movement of absolute knowledge, and this is the structure of the mind. Mediation deals with itself [Vermittlung des Sichanderswerdens mit sich selbst] and pushes the conceptual idea of self-change, self-transformation [begriffslogische Selbstveränderung] of the Absolute Subject (I. M.) as a theme of education, experience and science (Lütterfelds 2007, 84). 
the further development of knowledge, to the meaningful course of content methodology. The transition of the subjective idea to being becomes a reality with the presence of mediation in itself, not of mediation only with something external and through something external, "but as ending in itself". The awareness of this immanent totality and the inner impulse of mediation are both its establishment and constitution as a general regularity and an ontological principle. The unity, totality and universality that contain and promote the principle of mediation are not a presupposed, idealistic premise for the identity of subject and object in the mind. On the contrary, it is an endless course of self-realization, self-development, spiritual uplift aimed at achieving more and more powerful and more sustainable unity, from which to proceed again with confidence to further its development and improvement. In this way, mediation is understood, not only as an absolute beginning, not only as an end result, but as a speculative-dialectical process, a method of absolute negativity, the real course of thought definitions that build the structural lattice, the model of being. In such a structured being, each element contains the definition of its predecessor, and the preceding form is sublated in the other, subsequent form. Mediation, seen as selfrelation, spiritual self-movement, and self-transformation, going through a relationship with something else and with something else, is in fact a contradiction. Within the scope of this mediation, the contradictory content is not abandoned and neglected, but rises and provides for thinking. The mediated and mediating subjectivity in this way is an absolute subjectivity, on which it is possible to remove the contradiction between concept and reality and in general the existence of the personality [Persönlichkeit] and freedom.

From the speculative logic is derived the methodological meaning of the absolute, fundamental mediation, crystallizes its living spirit and true result, as the concrete, the subject. The form of this method is often understood only in its abstract element of trinity, but Hegel clearly shows that this form can also be taken as a quadruple, in which the negative, the difference is counted as duality, unity of mediation, absolute mediation (as sublation of the mediation). The duality here arises through the explicit nature of the systematic mediation between the "logical" and the "ethical". The single result is not something forever completed, but the restless one. Mediation is directed to oneself and one's own activity, manifesting the ethical element. After removing the mediation and the double negativity, the obtained Absolute Subject again gives itself a form of immediacy, a new beginning, with the further development of which its own content, already derived and already proved in logic, can be shown. The sublated mediation stands out as a form of the absolute method of knowledge, as the essential side of the absolute mediation. In this way, the Absolute Subject has in itself the peculiarity, the definiteness, which builds on its uncertainty as a beginning. The Absolute Subject is understood through the prism of the absolute method of mediation, as a system of totality. In it the content finds its further definition, in general, the general course of knowledge, from logic to ethical life, but also the reverse path is present, going back and justifying the beginning, the general course of being. 
In the specific case of the present work and the attempt to pave the way for the spiritual evolution of the personality, mediation, the mediating function of freedom is this center in which duality manifests itself methodologically, dissolves and sublates itself ontologically in the spirit. Through the course of knowledge and analysis of mediation, the ground crystallizes. Through all stages of development of logical categories, the need for transition to ethical life is known. In parallel with this move, however, at each next step of it, the return (the "going back justification") to the beginning, the other move, is made meaningful. Such is the absolute method of knowledge, as a system of wholeness, a circle that reproduces the absolute dialectic, the methodologically substantiated mediating function of freedom, which determines and establishes the typological characteristic of spiritual evolution. And the method understood in this way embodies not only its logical and epistemological significance, but also its ontological meaning. Insofar as the method, as an absolute and fundamental mediation, is an essential principle in logic, it becomes clear (or possible) from what has been said so far that it could be also a principle in the sphere of ethics.

The idea of the "state" as the embodiment of concrete freedom dominates in Hegel's Philosophy of Right. The constitution is the internal law of the state [das innere Staatsrecht], which contains the entire course of the absolute method. Therefore a careful and in-depth study of the constitution, of the internal state law, of the various functions, relations and activities in the state, to the greatest extent helps to establish mediation as an ontological principle of ethical life.

In the constitution, the state finds its support to unite the individual with the community. This is a kind of vortex in which the subjective interests and the intention to satisfy them in fact coincide with the goals of the universal and in fact work for its improvement and substantial construction. Thus, the level of constitutional law of a state, the meaning, goals, rights and obligations presented in its basic law, ultimately corresponds to the level of consciousness of individuals, citizens and their spiritual condition. In order to demonstrate concretely the mediation in this sphere, one should only consider the degrees of state structure and government, whose speculative-dialectical treatment leads to the absolute peak and culmination of self-development of the mediating function as world history and manifestation of the spirit.

The state is an internally organized whole, where the main requirement is the organization and realization of the concept of freedom. The institutions ("family" and "civic community") embody, guarantee and make sense of the constitution, the developed and updated rationality ${ }^{16}$. As the beginning of the state, the constitution and its content are immediate, in the sense and form of an abstract universality. The content of the

16 "They are the steadfast basis of the state, determining the temper of individuals towards the state, and their confidence in it. They are, moreover, the foundation-stones of public freedom, because in them particular freedom becomes realized in a rational form. They thus involve an intrinsic union of freedom and necessity" (Hegel 2005, 141-142). 
constitution is immediate, something simple and general, but in the element of thinking, not of the senses or the imagination. Thus, by virtue of the absolute method of mediation, the immediacy of the content of the constitution, in fact, acquires the meaning of being, of the abstract relation to oneself. The requirement that crystallizes at this final stage of the study, namely to show and interpret the meaning of the constitution as the absolute basis of the state, has the inner meaning of the further realization of the concept of freedom, of an realization that lies not only in the constitution, but is rather the goal and task of the Absolute Subject, of its development and spiritual evolution. Man knows his own, special interest and the possibility of its realization, for its transformation into being only in the state and its constant creation.

The constitution is not something completed once and for all. Due to its inseparable connection with the spirit, it is constantly evolving, passing the necessary degrees of change through the concept. As a pure universality, the constitution is dissatisfied and has a tendency to take itself further. It is in-it-self the concrete totality, but it is not set for-it-self. Thus in the beginning the constitution is expressed as being in-it-self without being for-it-self. The own evolution of the constitution, respectively of the spirit, consists in the way of being in-it-self, the self-determination of this common, as common for-it-self, as a subject ${ }^{17}$. In this course of the constitution the dismemberment of the state power, the living concrete totality in which the difference appears the definition in general, the government appears.

The separation of the legislative, executive and judicial power derives from the nature of the concept, i.e., through the act of mediation, in which the organizational structure of the state is revealed as the development of the idea in its differences. The state is not a mechanism (in the context of mechanistic materialism), but the course of the rational life of self-conscious freedom, the mediating activity and system of the

17 Here lies an idea that has a broader tradition in research in the field of social and legal philosophy, and in the history of ideas in general. It is a question of the thesis (a dogma) about the legal subjectivity, or legal personality of the state [Rechtspersönlichkeit des Staates], which has been treated in more recent times by the Swiss lawyer and social philosopher U. Häfelin. The thesis has no application in Switzerland, but has been extensively discussed in France and Germany since World War II. Häfelin examines historically and relatively the concept of legal personality of the state, noting that over time it becomes increasingly important. With the increase of the systematic importance of the law, the scope of the construction of the personality in connection with the overall concept of the state also increases. With the development of the idea of Staatpersönlichkeitsdogmas, in different epochs and in different legal schools, not only this state structure is designed. In many cases, this is an internal structural change in the concept of legal personality of the state. In this way, the Rechtspersönlichkeit des Staates is placed in a completely different systemic context from the individual schools (Häfelin 1959, 396-399). The problematic nature of this doctrine lies in the possibilities for establishing a relationship between the state and the individual, of different conceptualizations of the relationship between the universal law of the state and the individual character of the individual member of civic community.

In Pure Theory of Law (1934), H. Kelsen also considered the thesis of the legal personality of the state. Through the prism of the conception of the state as a social order and a national legal order, Kelsen also presents the state as a subject, in the sense of the personification of this order. If the state is interpreted as active subjectivity, then it is rather only the personification of the legal order, not as the overall legal order of the state (national), but as that of individual representatives (of different social spheres), in the context of the principles of division of labor (Kelsen 2005, 290311). 
ethical world. The separation of powers is understood as the vital soul of the state, as the absolute subjectivity, which simultaneously creates differences and preserves their unity. As a spiritual movement, domestic state law and its subdivisions are in harmony with the nature of the concept. This occurs when every power, government and class, as different, have in themselves the element of the whole, totality, i.e., they also contain elements of their differences. In this way an individual whole is constituted.

The dynamics in the work of individual authorities in the state should be bilateral. On the one hand, special spheres and individual cases fall under the general, as legislative power, but on the other hand, the possibility of unity of the state and the constitution is determined by the power of government (executive power) as administrative and judicial power depending on the application of laws relating to general or private matters. The legislature is not completely independent of other authorities, of the law in general, and of universally recognized legal principles and values. It fixes and establishes universal values. At the same time, it guarantees and constitutes the principle of free (absolute) subjectivity. Legislative power, as the first sphere of state manifestation, penetrates into all relations and codes of ethics, into the consciousness of all individuals ${ }^{18}$. As the creator of the laws in the state the legislature has in itself the spirit of the constitution and the people, has the inner impulse of the concept and strives for the further definition of the law and the universal values, which it stands for. It is also its connection with the executive branch, which further carries universal rights and values to their definite reality. For its part, the executive power carries out this activity, controlling and organizing the peculiarity and monitoring its misleading and coordination with the law and the general public.

The speculative-dialectical treatment of the Principle of the Separation of Powers requires a demonstration of the mediation within it, a methodological and ontological substantiation of both the mediation itself and the principle in question. Beyond the rational method of considering the nature and relation of the various powers, mediation has the dialectical in-it-self; rather it is the dialectical itself. In its negative element, mediation decomposes the definitions of reason, and in its positive element it gives rise to the universal and perceives in it the particular. In the general spirit of mediation, the legislature and the executive are the manifestation of negative and positive reason in the state. Mediation as a spiritual movement constitutes the qualitative side in the activity of the two authorities. Initially, the simplicity of universality and abstract law is denied in order to make the definite distinction to which the negation is again applied. Mediation continues after the negation of negation, and thus is the positive, in which the first universal, which is no longer abstract, is restored. Thus the laws, the universal rights and values become concrete within themselves, in the mediating activity of the spirit, both

18 "Hence the constitution of a people depends mainly on the kind and character of its selfconsciousness. In it are found both its subjective freedom and the actuality of the constitution" (Hegel 2005, 160). 
the universal and the particular are determined. Legislative and executive powers move in this definition, which is essentially the immanent development of the concept. Thus, in the ethical course that builds itself, with the power of mediation, absolute subjectivity is established.

It should be made clear that Hegel shows neither negative criticism nor blind adherence to the ideas of liberalism in its familiar classical form. As much as he was a supporter of the constitutional monarchy and declared himself against the revolutions, he also had a touch of conservatism. In the spirit of speculative-dialectical and mediation, he tries to build a bridge between the traditional conception of the monarchical constitution and modern liberal thinking, to introduce the emerging development of freedom in the model of the constitutional monarchy, thus building a system overcoming the shortcomings and one-sidedness. He sees the concrete existence of the spirit, of the constantly evolving concept of freedom, precisely in this removal of the classical liberal and conservative ideas, as a powerful speculative idea of the state, and hence of world history and the dialectic of the special spirits of nations.

"World history" [Weltgeschichte] is the culmination of the self-cause and selfrealization of reason in reality. As a spiritual movement, world history is the liberation of the moment in the spirit. It is an exposition and realization of the universal, absolute spirit. As the Absolute Subject rises to the level of world history, the power of mediation is concentrated and condensed even more than before, while at the same time its scope expands. The self-denial of the Absolute Subject, and in this self-denial the attainment of spiritual evolution, is the intensity in which mediation develops its potential as an absolute method of knowledge and methodological and ontological justification. Every work of world history contributes to the spiritual growth of the Absolute Subject, and the latter appears as an incarnation of the substantial activity of the world spirit. With awareness, with comprehension of the substantial in the course of mediation in world history, thanks to education in the field of speculative logic and its methods and principles, the Absolute Subject is the very top.

Hegel's philosophical view of world history is the very exposition of the absolute method of knowledge, of mediating activity. In his philosophical history, he views the world historical process as the self-liberation of man. All the basic principles of speculative logic are embedded in the world historical process, (i) absolute freedom; (ii) despotism and the freedom of a ruler (Eastern world); (iii) democratic and aristocratic rule in ancient Greece and ancient Rome; (iv) to the true monarchy and the German Christian world. These stages are seen as degrees in the consciousness of freedom, denying each other in a progressive direction, which direction is the necessary move from the abstract to the concrete, as well as the necessary unity of the sequence of logical and historical. Mediation achieves his goal by arranging and systemizing the historical facts, thus explicating the overall picture of the historical course of mankind and the logical connection of the 
particular spirits, of the different peoples. Hegel inserts mediation in the study of world history, and its cumulative nature contributes to the achievement, understanding and laying down of history.

The conceptual and systematic conception of history is the essential relation of the Absolute Subject, which sees the order (the substantial) in the initially revealed chaos and the series of coincidences in the process of historical development. Mediation requires the release of the immanent rhythm of the concept and the unfolding of the nature of the object from itself, without the intervention of subjective opinion, sensory observation, or the so called contemplation. Such freedom in the knowledge of world history is a basic requirement, moreover, it is the turning point from which one starts and ultimately achieves the necessary connection between the world historical process and the Absolute Subject, without the latter being subordinate to the former, and vice versa. For example, if the object of study is world history, and the subject of, say, French history in the eighteenth century and the beginning of the Great French Revolution, then the free course of conceptual thinking leads to the placement of internal, own causes. Reaching the self-consciousness of the French citizens, to the consciousness of freedom of reason, dictated and essentially prepared by the Enlightenment ideas and attitudes, inevitably sets itself the next goal, to come out into reality, to unleash the power by which victory over the feudal economic system and despotic monarchy will triumph. The inner form shows the own conception of the revolution and the parallel course of development and perfection of the human consciousness, its spiritual evolution. Absolute monarchy and the suppression of the economic activity of the rising bourgeoisie no longer satisfied the spirit of the French. They crave a new system of government and civic community, a state based on human rights and freedoms. This new spirit, which reached its consciousness of itself, went far beyond the geographical borders of France, becoming a major power throughout Europe and later beyond. Freedom of reason prepares the consciousness of mankind for the democratic reorganization of societies. The universality of the method penetrates both the object and the subject, and in the concrete example, the history of the revolution in France reveals the immanent course and internal activity of substantiality (legitimate deep social causes, the concept of being) to subjectivity (people's self-awareness of these causes, the concept as a concept).

Every nation (as a "historical individual") is a particular spirit in world history. The international influence of the Great French Revolution shows the need for dialectic of particular spirits and proves an even higher requirement for the interweaving of mediation in the world historical process. Preservation and cultivation of the peculiarity and originality of peoples, as well as simultaneous enrichment and improvement through the other (for example, France and Germany, in which progress in the consciousness of freedom takes place in different ways, but as a necessity for each of the forms) of the demonstrated methodology, which ultimately results in something third, such as the unity of duality. The unity of duality, like this third, is the essence of the Absolute Subject, 
and since each individual nation is part of world history, through the mediating function of freedom, the idea of the absolute subjectivity of the people and the state is reached. Here the subjective will and the substantial life merge into one ethical whole [Sittlichkeit] which has an ontological characteristic. The state is the real ethical life, the unity of the substantial and moral-subjective will, the ethical life in its entirety. Thus the latter, as such a unity, rises to a concrete universality, to mediated immediacy and reveals its ontological potential. Sittlichkeit is the spiritual reality that has its existence in the state. The Absolute Subject observes the ethical life of the state, which becomes its essential characteristic, understands its principles, which are one with its own beliefs and will, and lays down the paradigm of mediation as an ontological principle of ethical life. Within this paradigm lies the idea of a speculative-ethical project, which has yet to consider the possibilities for its application, a project in which the individual morality of each individual citizen and the ethical spirit of the state stand in speculative unity. Fundamental mediation is the method (spirit) by which this totality is made possible, the absolute method of knowledge, which also creates absolute subjectivity.

\section{Conclusion}

The Absolute Subject is considered as a necessary result of the speculativelogical education, as well as of the subsequent phenomenological approach to its own essence. The two paths merge into one, as ontologically sublated. The principle of the methodological function leads to the substantial side of the Absolute Subject, whose goal is the constant transformation and self-improvement, the spiritual evolution, the infinite change in which the peculiarity is preserved. In fact, from a pessimistic point of view, man's helplessness in the relentless course of the world historical process and the cunning of reason [List der Vernunft] stand out well. Logging the world, as some authors call it, unleashes a spiritual force that the human being cannot master, but simply serves, while thinking that he is achieving what he himself desires. However, the logic of the world is speculative; i.e., absolute subjectivity elevates its thoughts, feelings, and desires to the power of the absolute spirit, becomes one with it, builds on its own selfishness, low passions, and empty thoughts, and overcomes the cunning applied to it as a method of restraint.

Virtues and ethical life [Sittlichkeit] do not play a huge role in the world, in the historical process, because their level is low, in contrast to selfish goals, passions, etc., whose importance is elevated. Ordinary reason, which is actually accustomed to discipline and simple arithmetic (and has its necessary role, although it should not remain with it), cannot break the shackles and free the spirit, stands at its own extreme and extremes and degrades ethical life, transforms it in something stereotypical, unifies it, ultimately subordinating man and depriving him of his freedom. Man is reduced to the degree of a machine which operates with ordinary reason and, one after the other, the 
same calculation. The Absolute Subject dealing with fundamental mediation, educated in speculative logic, has the ability to transcend the ethical "values" of ordinary reason and to build its own, new values that time requires, as well as its higher education, level of self-awareness, and so on. This is the spiritual evolution itself and the present paper revealed a possible course for a meaningful sublation, preservation and accumulation, a meaningful construction of being [Gedachtsein], and its infinite attainment.

\section{References}

Aristotle 1999. Politics, trans. B. Jowett. Kitchener: Batoche Books.

Brooks T. 2017. "Hegel's Philosophy of Law," in D. Moyar (Ed.), The Oxford Handbook of Hegel. New York: Oxford University Press.

Del Vecchio G. 1921. The Formal Basis of Law, trans. J. Lisle. New York: The Macmillan Company.

Duplancic V. 2006. „Erfahrung der Freiheit: die Entwicklung der Freiheitsidee in der Phänomenologie des Geistes von G.W.F. Hegel." Doctoral Dissertation, Ruhr Universität Bochum. URL: https://www.academia.edu/1884156/Erfahrung der Freiheit die Entwicklung der Freiheitsidee in der Ph\%C3\%A4nomenologie des Geistes von GWF Hegel (retrieved on August 16, 2021).

Häfelin U. 1959. Rechtspersönlichkeit des Staates: Dogmengeschichtliche Darstellung. Tübingen: J. C. B. Mohr (Paul Siebeck).

Hegel G. W. F. 2010a. Encyclopedia of the Philosophical Sciences in Basic Outline. Part I: Science of Logic, trans. K. Brinkmann \& D. O. Dahlstrom. New York: Cambridge University Press.

Hegel G. W. F. 1977. Phenomenology of Spirit, trans. A. V. Miller. Oxford University Press.

Hegel G. W. F. 2005. Philosophy of Right, trans. S. W. Dyde. New York: Dover Publications, INC. Mineola.

Hegel G. W. F. 2010b. The Science of Logic, trans. G. Di Giovanni. New York: Cambridge University Press.

Jaeschke W. 2003. Hegel-Handbuch: Leben - Werk - Schule. Stuttgart - Weimar: Verlag J. B. Metzler.

Kelsen H. 2005. Pure Theory of Law, trans. M. Knight. New Jersey: The Lawbook Exchange, Ltd. Clark.

Lasson A. 1967. System der Rechtsphilosophie. Berlin: Walter de Gruyter Verlag. Lütterfelds W. 2007. „Hegel's Identitätsthese von der Substanz als Subjekt und die dialektische Selbstauflösung begrifflicher Bestimmungen," Synthesis Philosophica 22(1):59-85. 
Pippin R. B. 2000. “Hegel's Practical Philosophy: The Realization of Freedom,” in K. Ameriks (Ed.), The Cambridge Companion to German Idealism (pp. 180-199). New York: Cambridge University Press.

Rosenkranz K. 1844. G. W. F. Hegel's Leben. Berlin: Verlag von Duncker und Humblot.

Sabine G. H. 1933. "Rudolf Stammler's Critical Philosophy of Law," Cornell Law Review 18(3):321-350.

Stammler R. 1925. The Theory of Justice, trans. I. Husik. New York: The Macmillan Company.

Wood A. W. 1990. Hegel's Ethical Thought. Cambridge: Cambridge University Press.

Wood A. W. 1993. “Hegel's Ethics," in F. C. Beiser (Ed.), The Cambridge Companion to Hegel (pp. 211-233). Cambridge: Cambridge University Press. 